\title{
Relationship between Level of Compliance with Statement of Accounting Standards and Performance of Nigerian Banks
}

\author{
(Mrs.) Khadijat Adenola Yahaya (Corresponding author) \\ Department of Accounting and Finance \\ University of Ilorin, Nigeria \\ E-mail: khadijatadenola@yahoo.com,yakhadijat@unilorin.edu.ng \\ Abdulrasheed Abdulraheem \\ Department of Accounting and Finance \\ University of Ilorin, Nigeria \\ E-mail: Abdulrashraheem@yahoo.com \\ Ramat Titi Salman \\ Department of Accounting and Finance \\ University of Ilorin, Nigeria \\ E-mail: titisalman@yahoo.com \\ Oyebola Fatimat Etudaiye-Murhtar \\ Department of Accounting and Finance \\ University of Ilorin, Nigeria \\ E-mail: fatimaetudaiyemuhtar@yahoo.com
}

$\begin{array}{ll}\text { Received: January 3, } 2012 & \text { Accepted: February 14, } 2012 \quad \text { Published: March 16, } 2012 \\ \text { doi:10.5539/ijbm.v7n6p128 } & \text { URL: http://dx.doi.org/10.5539/ijbm.v7n6p128 }\end{array}$

\begin{abstract}
In Nigeria, the Statement of Accounting Standards (SAS), Companies and Allied Matters Act (CAMA) and the Central Bank of Nigeria's directives and regulations provide guidelines to banks in preparation and presentation of records of financial transactions. In recent time, some Nigerian banks appear to be engaging in non-standardized and unprofessional practices, which could lead to distress and liquidation. The objective of this study therefore was to investigate the relationship between level of compliance with Statement of Accounting Standards and performance of Nigerian banks. Twenty selected banks quoted on the Nigerian Stock Exchange formed the target sample and these were banks whose Annual Financial Reports for the period of study were fully available. Both primary and secondary sources of data were employed in carrying out the study. A researcher-designed questionnaire was used to obtain data from Senior and Managerial staff of each of the banks. The instrument was structured to accommodate the sixteen Statements of Accounting Standards which are related to banks and used in the assessment of banks' compliance. Five hundred questionnaires were administered to the Senior and Managerial staff of the selected quoted banks. The Annual Financial Reports of the selected banks from 2005-2009 (post-consolidation era) were also used. The collected data were analyzed using CAMEL Ratios, and Pearson correlation analysis. The findings of the study indicated a significant positive relationship between level of compliance with SAS and banks' performance. In line with the findings, it was recommended that the Nigerian Accounting Standards Board (NASB) should ensure effective monitoring of banks in order to enforce compliance, especially among banks that are performing below standard. The need to adopt International Accounting Standard practice among Nigerian banks was also emphasized.
\end{abstract}

Keywords: Relationship, Compliance, Statements of accounting standards, Banks’ performance 


\section{Introduction}

Banks are essential sector in the development of any nation. They facilitate efficient mobilization of human and material resources, pooling of savings and allocation of funds to the investment outlets. Banks also provide liquidity and capital to firms in their production processes and facilitate a reliable payment system; thus providing a variable platform for an effective monetary policy management. They provide opportunities for financial transactions and manage the financial assets and liabilities of other economic units of a nation. Banks mobilize deposits, provide credits, and offer professional advice to investors and act as agents of government in the implementation of various monetary and macro-economic policies. In Nigeria, banks have been accepted as catalysts to national development. For instance, the Fourth National Development Plan (1981-1985) emphasized that the banking system in Nigeria would continue to be encouraged and guided to respond to the challenges of national development. Similarly, Izedonmi (2001) noted that banks help to allocate available resources by mobilizing funds from non-productive channels to finance investment activities in productive sectors and increase capital formation. According to the author, banks also promote financial integration of the various sectors in Nigeria. This is because funds are mobilized from areas with surplus funds to areas of deficit. Financial information is crucial for the economy and the quality of financial statements depends on the accounting standards on which they are based.

Financial statement forms the basis on which economic and financial agents, as well as authorities take their decisions. Accounting standards have a direct impact on supervisory work and on central banks' oversight given that banks' accounts form the basis for calculating financial and regulating ratios. Hence, non-compliance with the Accounting Standards and rules affect market perception, financial ratios and reports that supervisors use for assessing both the condition of individual banks and along with central banks, the global condition of the financial system. The Accounting profession, through the issuance of standards, provides direction and guidance on how banks and business enterprises could achieve the goal of proper record keeping, transparency, uniformity, comparability and enhancing public confidence in financial reporting. Thus, failure on the part of the firm to apply the requirements of accounting standards result in inconsistencies, lack of accountability, transparency, and distortions in financial reports, which in turn results in poor financial reporting practices and dissemination of accounting information that is of less value to any particular group of users. This is because the preparation and presentation of financial statements lacks objectivity, reliability, credibility and comparability, and thus, results in fraudulent business practices, which subsequently lead to business failure, and become devastating on the national economy (Katundu, 2005). However, despite the importance and endless benefits that accrue to an economy through effective compliance with accounting standards, there have been only few studies conducted in the area. As far as the researcher is aware, there are only few studies on the relationship between banks' level of compliance with statement of accounting standards and performance of Nigerian Banks. Consequently, this study is an attempt to fill this gap.

\subsection{Statement of the Problem}

In the last two decades, the Nigerian banks have been experiencing a lot of challenges. For instance, Soludo (2004) stated that the Nigerian banking system was fragile and marginal to the extent that the system faces enormous challenges which include persistent illiquidity, unprofitable operations and poor asset base. $\mathrm{He}$ stressed further that Nigerian banks appeared to have abandoned their essential intermediation role of mobilizing savings and that low capitalization of banks had made them less able to finance the economy and more prone to unethical and unprofessional practices. This led to the introduction of economic reforms in the banking sector by the Federal Government of Nigeria. One of such reforms was the re-capitalization. The reform in the banking sector of the economy led to the subsequent merger and acquisition of banks between 2004 and 2005. The banks that could not meet up with the N25 billion re-capitalization benchmarks had to merge with other banks, while those that could not merge collapsed. Also, on the 14th August, 2009, the Central Bank of Nigeria, following the results of its special examination of 10 out of the 24 banks in the country, removed the executive management team of five banks; namely, Fin Bank of Nig. Plc, Intercontinental Bank Plc, Oceanic Bank International (Nig) Plc, United Bank of Africa Plc and Union Bank of Nigeria Plc. In September of the same year, the audit of the remaining 14 banks was completed with 5 found to be unhealthy. The Managing Directors/Chief Executives as well as executive directors of 3 of the banks were removed while 2 banks were given up to June 2010 to recapitalize. A total bail- out fund of N620 billion was injected into the industry in order to stabilize their operations. The failure of some banks as generated a lot of concerns among stakeholders in private and public organizations and the need for enforcement of accounting and financial reporting standards have been stressed. 


\subsection{Hypotheses}

Hypothesis One:

Ho: Nigerian quoted banks are not significantly different in their levels of compliance with Statement of Accounting Standards (SAS).

Hypothesis Two:

Ho: There is no statistically significant relationship between the level of compliance of the Nigerian quoted banks with Statement of Accounting Standards and their performance in terms of profitability.

\subsection{Scope of the Study}

The study examined the relationship between the level of compliance with the statement of accounting standards and performance of Nigerian Banks between 2005 and 2009. The choice of this period is that in 2004 there were 89 banks but after capitalization they were reduced to 24 banks, some banks collapsed and were on longer existing. For continuity and consistency post consolidation period was choose which is between 2005 and 2009 . The Nigerian Accounting Standards Board (2003) is the only recognized independent body in Nigeria responsible for the development and issuance of accounting standards for users and these who prepare financial statements, investors, commercial enterprises, banks and regulatory agencies of government since 1982. Out of the 30 Statement of Accounting Standards (SAS) issued so far, only 16 relevant SAS were used. The SAS were restricted to only 16 out of the 30 SAS because the others Statement of Accounting Standards relate to Insurance companies, telecommunications, petroleum industries etc. Out of the twenty-four banks in Nigeria, the study was restricted to only twenty quoted banks on the Nigerian Stock Exchange.

\section{Literature Review}

\subsection{Conceptual Framework}

Izedonmi (2001) defined accounting standard as an information system through which financial and monetized information is generated for economic, social and political decisions. According to him, statements of accounting standards are developed to ensure a high degree of standardization in publishing financial statements. The procedure provides necessary guides on how accounting information should be prepared and presented in order to enhance the value of its contents and facilitate thorough understanding. Accounting standards are not only developed to ensure a high degree of standardization and uniformity in publishing of companies' financial statement, but they are also useful to all users of accounting information. Banks' compliance with accounting standards ensures standardization and efficiency in financial reporting. Accounting standards also have a significant impact on the financial system, in particular, via their potential influence on the behaviour of economic agents. Accounting standards are guidelines which define how companies have to display transactions and events in their financial statements. These are not purely technical rules but they are the outcome of highly political processes (Fogarty, Hussein \& Ketz, 1994). This means that there are different actors who come into contacts with or are influenced by accounting standards - e.g. preparers, managers, accounting firms, auditors, financial analysts and employees. All these actors might have different options and interests about what an accurate and useful accounting standard is and therefore might have different incentives in the production and diffusion of accounting standards (Giner \& Arce, 2004). Although, academics and practitioners agree on the importance of compliance with the requirements of accounting standards as an essential element of financial reporting infrastructure, many scholars argue that the extent to which standards are enforced and violations prosecuted are as important as the standards themselves (Sunder 1997). Thus, the quality of financial information is a function of both the quality of accounting standards and the regulatory enforcement or corporate application of the standards (Kothari, $2000 \&$ Hope, 2003). Absence of adequate enforcement, therefore, renders the best accounting standards inconsequential. This is because if nobody takes action when rules are breached, the rules remain requirements only on paper. However, in some environments, firms behave towards "mandatory" requirements as if they were voluntary (Giner \& Arce, 2004; and Cooper \& Robson, 2005). Even though accounting policy disclosures are required in most countries as well as by IAS 1 (Frost \& Ramin, 1997) document considerable variations in accounting policy disclosures within and across countries. The importance of compliance with the requirements of accounting standards is that it enhances transparency, accountability, standardization, uniformity and comparability which in turn enriches the quality of decision of the users and helps in proper allocation of resources in an economy.

\subsection{Need for Accounting Standards in Banks}

The main objective of standardization is to protect the interests of the shareholders and other stakeholders. The level profitability and extent, to which business assets are secured, therefore become important items of concern 
to all stakeholders (Kasum, 2011). The high level of distress in the banking sector has spurred the regulatory and supervisory authorities to examine more rigorously the safety and soundness of the banks by assessing the extent of level of compliance to the Nigerian Accounting Standards Board. Also, legal reform policies aimed at empowering the board to deal more expeditiously with problems of distress in the financial institutions are being sponsored at the National Assembly. The issuance of the Statement of Accounting Standards (SAS) to Banks and Financial Institutions is aimed at promoting consistency in reporting by banks, greater disclosure and more prudent provision for bad and doubtful debts (Ebhodaghe, 1997).

\subsection{Empirical Framework}

In a related study, Wallace (1988) examined the disclosure practices of Nigerian companies as related to the requirements of the Nigerian Accounting Standards Board. The study found that company size, ownership structure, company age, multinational affiliation, auditor's size, number of employees; stock exchange listing and profitability are associated with disclosure level. Venkatachalam (1999) investigated the impact of IAS based accounting statements' compliance with US GAAP, through form 20-F reconciliation. He found out that conversion to US GAAP is value relevant. Based on his findings, he suggested some extensions to these requirements. Form 20-F is the form completed by non-US companies listed on US stock market to reconcile their accounts to US GAAP, if US GAAP is not the original bases of preparation.

Izedonmi (2001) examined the level of banks' compliance with accounting standards and the overall empirical evidence suggested that quoted banks largely complied with the requirement standards. Adeyemi (2005) studied the impacts of compliance with financial reporting standards on organisational performance. The sample comprised 96 companies in Nigeria. The findings of the study showed that Nigerian companies comply with accounting standards reasonably well. The level of compliance was, however, less than the international benchmark of $91 \%$, and there were variations in the depth of disclosure by the studied companies. The study also found that compliance with accounting standards had a significant positive impact on the performance of the companies. There was no significant relationship between companies' sizes and compliance with accounting standards. Kantudu (2005) examined the level of Nigerian Quoted Companies' compliance with the requirements of SAS No 2 that is information to be disclosed in financial statement. Based on a study of 25 sample firms covering a period of 5 years $(1998$ - 2003), the study found that gap existed between standard requirements and disclosure practice of the listed firms. In a similar research, Kantudu (2006) investigated the impact of enforcement power given to Nigerian Accounting Standards Board on compliance, specifically, with the standard on employees' retirement benefits. The investigation covered a period of 10 years and 30 companies. The findings of the study indicated that the Act significantly influenced the application index. The study, however, showed that there was less variability on the application of accounting standards on employees' retirement benefits. Oghuma and Iyoha (2006) investigated the level of compliance of listed insurance companies with accounting standards. The study evaluated 15 out of the 25 listed insurance companies in Nigeria based on their compliance with 11 relevant standards. The findings revealed that quoted insurance companies generally complied with disclosure requirements of statement of accounting standards. However, in few situations where they did not comply, the concerned companies preferred to pay penalty, because payment of penalty was considered cheaper than compliance. Kantudu (2008) worked on the impact of NASB act on compliance with accounting standards on employees' benefits in Nigeria and the results from the analysis shows that a gap exists between what insurance companies do and what is required of them by SAS 16, that is, compliance with the requirements of SAS 16 by listed insurance companies is good (i.e. $76.9 \%$ ) and by the author criterion it was referred to it as compliance within the semi-strong range, which he discovered to be inadequate, because accounting standards are expected to be complied with in total, that is $100 \%$ compliance. Kasum (2011) investigated the impact of compliance with accounting standards on assets and profitability of Nigerian quoted companies. The study sampled forty-four companies quoted on the Nigerian Stock Exchange. Profitability, assets and compliance data of the companies were collected and analysed using Pearson's Product Moment and Spearman's Rank-order Correlation statistics. The study indicated that Nigerian companies reasonably complied with accounting standards but the level of compliance was below international benchmark and that compliance resulted in improved profitability. Based on the findings, the researcher suggested the need for constant review of accounting standard procedures in Nigeria.

\subsection{Theoretical Framework}

Adeniji (2004) described financial accounting is a scientific procedure of ascertaining the results and performance of any business on a periodic basis. Assessment of banks' compliance with statement of accounting standards and performance is a function of financial accounting. It is a process of identifying, measuring and communicating economic information to permit judgments and decision by users of such information. The main 
purpose of preparing financial accounts is to enable management render accounts of stewardship in terms of the profit generated in relation to the assets invested in the business (Omolehinwa, 2002). The preparation of financial accounting should conform to Generally Acceptable Accounting Principles, Statements of Accounting Standards, government regulations and the relevant provisions of the 1990 Company and Allied Matters Decree. Such standardized rules are necessary to facilitate communication between the business and investors from the outside world that may wish to obtain and compare information on Nigerian banks.

\subsection{Performance of the Nigerian Banking Industry}

The banking industry in Nigeria has witnessed a tremendous growth over the past years. This assertion is borne out of the number of banks and bank branches, their total deposits, total investments, total loans and advances and the profitability of the industry. For instance, the number of banks in Nigeria increased from 11 in 1960 to 45 at the end of 1990. According to Nigerian Deposit Insurance Corporation (1991) Annual Report and Statement of Accounts, the number of banks has increased from 45 in 1986 to 119 at the end of 1991, representing an increase of more than two folds. These 119 banks at end of 1991 were made up of 25 State- Government owned Commercial banks, 8 Federal-Government owned Commercial Banks, 32 Privately-owned Commercial Banks, 8 Federal/State-Government owned Merchant Banks and 46 Privately-owned Merchant Banks. The introduction of the Structural Adjustment Programme (SAP) in 1986 as an economic reform package was designed to liberalize the economy with emphasis on the financial system. The SAP era witnessed many policy measures that have continued to shape developments in the sector till the present day. The number of licensed banks shot up from 119 in 1991 to 120 in 1992 and in the same year, the sector recorded the existence of over 500 finance houses, 121 Bureau de change and about 300 community banks, among others. The numbers of banks reduced to 24 in the year 2004 as a result of re-capitalization programme of the Federal Government (Central Bank of Nigerian Annual Report 2003).

\section{Research Methodology}

The Nigerian banking sector is the population of the study. The sample size comprised Senior and Management staff of the twenty selected quoted banks in Nigeria. For the purpose of this study, twenty- five percent of the target population was randomly selected. Five hundred Management and senior staff participated in the study. Both the descriptive and inferential statistical tools were used in examining objective. These included percentages, mean score of responses and multiple regression models.

\subsection{Model Specification}

The formulated model by Wirnkar and Tanko (2008) was adopted for this study and used to examine the performance of Nigerian banks in terms of profitability using CAMEL rating system which was chosen as the measure of performance in the study. Spilling from theoretical understanding in the relationship between banks performance and statement of accounting standards, we postulate the performance as CAMEL.

Where $\mathrm{C}=$ Capital adequacy, $\mathrm{A}=$ Asset quality, $\mathrm{M}=$ Management quality, $\mathrm{E}=$ Earnings ability, $\mathrm{L}=$ Liquidity

However, given the different division and definition of each of the sub- variables in the main CAMEL measure, the total sum of the sub variable multiply by the number of the sub variables in monetary term is projected as the dependent variable. In this wise, we postulate CAMEL as:

$$
\begin{gathered}
1 / \mathrm{n} \sum_{\mathrm{i}=5}^{\mathrm{n}} \mathrm{c}=\mathrm{C} ; 1 / \mathrm{n} \sum_{\mathrm{i}=2}^{\mathrm{n}} \mathrm{a}=\mathrm{A} ; 1 / \mathrm{n} \sum_{\mathrm{i}=1}^{\mathrm{n}} \mathrm{m}=\mathrm{M} ; 1 / \mathrm{n} \sum_{\mathrm{i}=2}^{\mathrm{n}} \mathrm{e}=\mathrm{E} ; 1 / \mathrm{n} \sum_{\mathrm{i}=2}^{\mathrm{n}} \mathrm{l}=\mathrm{L} \\
\text { Such that; CAMEL }=1 / \mathrm{n} \sum \mathrm{c}+1 / \mathrm{n} \sum \mathrm{a}+1 / \mathrm{n} \sum \mathrm{m}+1 / \mathrm{n} \sum \mathrm{e}+1 / \mathrm{n} \sum 1 \\
\text { CAMEL }=\mathrm{F}\left(\mathrm{X}_{1}, \mathrm{X}_{2}, \mathrm{X}_{3}, \mathrm{X}_{4} \ldots . \mathrm{X}_{16}\right)
\end{gathered}
$$

Where $\mathrm{CAMEL}=$ Independent variable as derived above, $\mathrm{X}_{1}=$ Disclosure of Accounting Policy (SAS1), $\mathrm{X}_{2}=$ Information to be disclosed financial statement (SAS2), $\mathrm{X}_{3}=$ Accounting for property, plant and equipment (SAS3), $\mathrm{X}_{4}=$ Extraordinary items and prior adjustments (SAS6), $\mathrm{X}_{5}=$ Foreign currency conversions and transaction (SAS7), $X_{6}=$ Accounting for employee's retirement benefits (SAS8), $X_{7}=$ Accounting for depreciation (SAS9), $\mathrm{X}_{8}=$ Accounting for banks and non-bank financial institution I (SAS10), $\mathrm{X}_{9}=$ Accounting for leases (SAS11), $X_{10}=$ Accounting for deferred (SAS12), $X_{11}=$ Accounting for investment (SAS13), $X_{12}=$ Accounting by bank and non-bank financial institutions II (SAS 15); $\mathrm{X}_{13}=$ statement of cash flows (SAS18), $\mathrm{X}_{14}$ $=$ Accounting for taxes (SAS 19), $X_{13}=$ statement of cash flows (SAS18), $X_{14}=$ Accounting for taxes (SAS 19). 


\section{Results}

\subsection{Testing of Hypothesis}

An attempt was made to investigate the possibility of a statistical relationship between the level of compliance with SAS and the performance of Nigerian Banks. In order to accomplish this, Pearson correlation analysis was carried out. The result is presented in Table 1 (appendix). The table showed that the correlation coefficient ( $\mathrm{r}$ ) is 0.610 . That is, there is a positive significant correlation between level of compliance with SAS and performance of Nigerian Banks. This implies that the more the level of compliance, the better the performance of the banks. The correlation is significant at 0.05 level. We therefore reject the null hypothesis which states that there is no significant difference between the level of compliance with Statement of Accounting Standards and accept the alternative hypothesis which states there is significant difference between the level of compliance with Statement of Accounting Standards. The backward elimination regression model was chosen as the lead equation based on a- priori expectation of the standard regression estimation and the F- value of the overall. Table 1showed that the coefficient of multiple determination $\left(\mathrm{R}^{2}\right)$ which is the proportion of variation in performance of the banks jointly explained by the independent variables is 0.97 . This implies that about $97 \%$ of the variations in the performance of the banks are jointly explained by the independent variables. The remaining $13 \%$ is due to other variables not included in the model. The multiple linear regression models is significant at 0.05 level. The results revealed that seven variables namely; SAS3 i.e. accounting for property, plant and equipment $\left(\mathrm{X}_{3}\right)$, SAS8 i.e. Accounting for employee's retirement benefit $\left(\mathrm{X}_{6}\right)$, SAS10 i.e. Accounting for banks and non bank $\left(\mathrm{X}_{8}\right)$, SAS11i.e. Accounting for lease $\left(\mathrm{X}_{9}\right)$, SAS13 i.e. accounting for investment $\left(\mathrm{X}_{11}\right)$, SAS19 i.e. accounting for taxes $\left(\mathrm{X}_{14}\right)$, SAS20 i.e. abridged financial statements $\left(\mathrm{X}_{15}\right)$, SAS21 i.e. earning per shares are significant determinants of banks performance. But only three variables namely SAS3 accounting for property, plant and equipment, SAS8 Accounting for employee's retirement benefit and accounting for taxes i.e. SAS19 are statistically significant at 0.05 level. we therefore reject the null hypothesis which states that there is no statistically significant relationship between the level of compliance of the Nigerian quoted banks with Statement of Accounting Standards and their performance in terms of profitability, and accept the alternative hypothesis which states that there is statistically significant relationship between the level of compliance of the Nigerian quoted banks with Statement of Accounting Standards and their performance in terms of profitability

\subsection{Empirical Results of CAMEL Ratios}

Table 2 showed the results of the CAMEL financial ratios of the selected banks from 2005-2009. The result revealed that Oceanic Bank has the highest ratio of 5.68 while Sterling Bank has the lowest ratio of 1.98. This could be due to low capital base, low asset quality and poor liquidity. The summation of the CAMEL ratios results was used as the independent variable in the linear regression model. While the sixteen statement of accounting standards which include SAS1, SAS2, SAS3, SAS6, SAS7, SAS8, SAS9, SAS10, SAS11, SAS12, SAS13, SAS15, SAS18, SAS19, SAS20, and SAS21 were used as the independent variables.

\subsection{Discussion of findings}

In terms of magnitude SAS8 i.e. accounting for employee's retirement benefit ( $\mathrm{t}=7.20)$, SAS19 i.e. accounting for taxes $(\mathrm{t}=6.79)$ and SAS3 i.e. accounting for property, plant and equipment $(\mathrm{t}=6.86)$ have strong relationship with bank performance which also goes in line with the results obtained by Izedonmi (2001) that quoted banks do comply with the requirements of the standards. It was empirically established that the compliance with statement of accounting standards positively influenced the performance of Nigerian banks were SAS3 i.e. accounting for property, plant and equipment $\left(\mathrm{X}_{3}=1.807\right)$, SAS6 i.e. extraordinary items and prior adjustments $\left(\mathrm{X}_{4}=1.644\right)$, SAS10 i.e. accounting for banks and non-bank financial institution part I $\left(\mathrm{X}_{8}=0.381\right)$, SAS11 i.e. accounting for leases $\left(X_{11}=0.11\right)$, SAS13 i.e. accounting for investment $\left(X_{13}=0.821\right)$, SAS19 i.e. accounting for taxes $\left(\mathrm{X}_{14}=3.854\right)$, SAS20 i.e. abridged financial statements $\left(\mathrm{X}_{15}=0.805\right)$, and SAS21 i.e. earning per shares $\left(\mathrm{X}_{16}=0.877\right)$. While SAS1 i.e. disclosure of accounting policy $\left(\mathrm{X}_{1}=-1.88\right)$, SAS2 i.e. information to be disclosed in the financial statement $\left(\mathrm{X}_{2}=-0.05\right)$, SAS7 i.e. foreign currency conversions and transaction $\left(\mathrm{X}_{5}=-1.396\right)$, SAS8 i.e. accounting for employee's retirement benefit $\left(\mathrm{X}_{6}=-1.396\right)$, SAS9 accounting for depreciation $\left(\mathrm{X}_{7}=\right.$ -1.38), SAS12 i.e. accounting for deferred taxes $\left(\mathrm{X}_{10}=-0.75\right)$, SAS 15 i.e. accounting for banks and non-bank financial institution part II $\left(\mathrm{X}_{12}=-0.09\right)$ and SAS18 i.e. statement of cash flows $\left(\mathrm{X}_{13}=-1.013\right)$ has negative influenced on performance.

\section{Conclusion and Recommendations}

There is a positive relationship between compliance with Statement of Accounting Standards and performance of Nigerian banks. Most of the standards were met with high level of compliance while only few recorded low level of compliance. It was observed that although the Nigerian Accounting Standards Board and Institute of 
Chartered Accountants of Nigeria require mandatory compliance with all SAS, none of these bodies effectively sanctioned the defaulting banks for non-compliance. Effective machinery need to be put in place by NASB to ensure effective compliance with the standards set. At times, some banks deliberately break the law without being properly sanctioned. Also the Nigerian banks should improve upon their level of compliance of those statements of accounting standards that have least magnitude in order to enhance bank performance and maintained their compliance with those statements of accounting standards that have positive significance to bank's performance.

In line with the findings, it was recommended that:

1) The Nigerian Accounting Standards Board (NASB) should ensure effective monitoring of banks in order to enforce compliance, especially among banks that are performing below standard.

2) The need to adopt International Accounting Standard practice among Nigerian banks was also emphasized.

3) The Corporate Affairs Commission should ensure banks' compliance with standards. This can be done by levying fines or refusing to accept subsequent financial statements prepared in the same manner by such banks or nullifying their names from the list of registered banks.

4) The CBN should levy fines or carry out an outright withdrawal of the license of such banks too. The Nigerian Stock Exchange should ensure compliance with the accounting standards by imposing fines on the erring banks. Such banks could also be suspended from trading on the Stock Exchange market for two consecutive years. The delisting is important as some banks may prefer to break the law and pay fine rather than to comply when compared with the cost of compliance.

5) Banks should improve on their level of disclosure of accounting policy, foreign transaction and employees' retirement benefit. There is the need for banks to provide job security to their employees and better retirement benefit. Therefore for banks to improve their performance there is the need for them to disclose all the accounting policy. This include disclosure of fundamental accounting convention, concepts, accounting bases and procedures adopted in the preparing and presenting of financial statements.

\section{References}

Adeniji, A. A. (2004). An Insight into management accounting. Lagos: Value Analysis Consult.

Adeyemi, S. B. (2005). The Impact of Accounting Standard on Financial Reporting. Unpublished Ph. D. Thesis, University of Lagos.

Annual Financial Statement Reports of all quoted banks on NSE from 2005 to 2009. Ilorin: Nigerian Stock Exchange.

Central Bank of Nigeria. (2003). Annual Report. Abuja: CBN.

Choi (1997). International Accounting and Finance Handbook. (2nd Ed.). New York: John Wiley \& Sons.

Companies and Allied Matters Decree. (1990). Allied Matters Decree Abuja: Federal Government of Nigeria.

Cooper, D. J., \& Robson, K. (2005). Accounting, profession and regulations: Bringing Accounting Firms. Paper presented at the 28th Annual Congress of the European Accounting Association, Goteborg, 18th-20th May.

Ebhodaghe, J. U. (1997). Financial distress and failure resolution. Nigerian Deposit Insurance Commission. Abuja: NDIC.

Fogarty, T. J., Hussein, M. E. A., \& Ketz, J. E. (1994). Political aspects of financial accounting standard setting in the USA. Accounting, Auditing and Accountability Journal, 7(4), 24-46. http://dx.doi.org/10.1108/09513579410069830

Frost, C. A., \& Ramin, K. P. (1997). Corporate financial disclosure: A global assessment. In F. D. S. Choi (Ed.), International Accounting and Finance Handbook. New York: John Wiley \& Sons.

Giner, B., \& Arce, M. (2004). Lobbying on accounting standards: The due process of IFRS 2 on share-based payments. Paper presented at the 3rd International Workshop on Accounting and Regulation, Siena, 30th September-2nd October.

Hope, O. K. (2003). Firms' level of disclosures and the relative roles of culture and legal origin, Working Paper (Joseph L. Rotman School of Management, University of Toronto).

Izedonmi, F. O. I. (2001). An evaluation of the level of banks' compliance with accounting standards issued by the Nigerian Accounting Standards Board (NASB). The Nigerian Banker (July-December, 12-9). 
Kantudu, A. S. (2005). The Degree of Compliance with the Requirement of Information to be Disclosed in Financial Statement by Listed Firms in Nigeria. Abuja management Review, 3(1), 26-46.

Kantudu, A. S. (2006). Impact of Nigerian Accounting Standard Board Act 2003 on Compliance with Accounting Standard on Employee Retirement Benefit in Nigeria. Working paper Series (Accounting Department, Bayero University Kano, Nigeria).

Kantudu, A. S. (2008). Impact of Nigerian accounting standard board act 2003 on compliance with accounting standards on employees' retirement benefits in Nigeria. Accounting Department, Bayero University.

Kasum, A. S. (2011). The Impact of Compliance with Accounting Standards on Assets and Profitability of Nigerian Quoted Companies. The Journal of Commerce, 3(3), 2220-6043.

Kothari, S. P. (2000). The role of financial reporting in reducing financial risks in the market. In E. S. Rosengren, \& J. S. Jordan (eds.), Building an infrastructure for financial stability. Federal Reserve Bank of Boston Conference Series No. 44, June 2000.

Nigerian Accounting Standard Board .(2003). Nigerian Accounting Standards Board Acts. Lagos: NASB.

Nigerian Deposit Insurance Corporation. (1991). Annual Report and Statement of Accounts.

NSE. (2009). The Nigerian Stock Exchange Fact Book. Lagos: NSE.

Oghuma, R., \& F. Iyoha (2006). Compliance with Accounting Standards by Quoted Insurance Companies in Nigeria: An Empirical Investigation. Nigerian Journal of Education Research, 7(2), 18-27.

Omolehinwa, E. O. (2002). Coping with cost accounting. Lagos: Pumark Nigeria limited.

Soludo, C. (2004). Consolidating the Nigerian banking industry to meet the development challenges of the 21 st Century. Present at the special meeting of the Bankers' Committee (July 6, 2004), Abuja.

Sunder, S. (1997). Theory of accounting and control. Cincinnati, Ohio, South Western.

Venkatachan, M. (1999). Are 20-F reconciliation between IAS and US GAAP value relevant? Discussion. Journal of Accounting and Economics, 26(1-3), 313-318. http://dx.doi.org/10.1016/S0165-4101(99)00004-X

Wallace, R. S. O. (1988). Corporate Financial Reporting in Nigeria. Accounting and Business Research, 18(72), 352-362.

Wirnkar, A. D., \& Tanko, M. (2007). Camel(s) and Banks' Performance Evaluation: The Way Forward. [Online] Available: Http://Ssrn.Com/Abstract1150968. 13/06/2009 
Table 1. Empirical results of the Regression model of the compliance with SAS and performance of Nigerian banks 2005-2009

\begin{tabular}{|c|c|}
\hline Variable & Coefficient and $\mathrm{t}-$ value \\
\hline Intercept $(\mathrm{t})$ & $-6.12(-1.35)$ \\
\hline $\mathrm{X} 1 \mathrm{t})$ & $-1.88(-1.49)$ \\
\hline $\mathrm{X} 2(\mathrm{t})$ & $-0.056(-0.028)$ \\
\hline $\mathrm{X} 3(\mathrm{t})$ & $1.51(3.24)^{* *}$ \\
\hline $\mathrm{X} 4(\mathrm{t})$ & $3.48(2.38)$ \\
\hline $\mathrm{X} 5(\mathrm{t})$ & $-2.32(-2.06)$ \\
\hline $\mathrm{X} 6(\mathrm{t})$ & $-2.44(-3.24)^{* *}$ \\
\hline $\mathrm{X} 7(\mathrm{t})$ & $-1.38(1.28)$ \\
\hline $\mathrm{X} 8(\mathrm{t})$ & $0.38(0.29)$ \\
\hline $\mathrm{X} 9(\mathrm{t})$ & $0.11(0.13)$ \\
\hline $\mathrm{X} 10(\mathrm{t})$ & $-0.75(-0.74)$ \\
\hline $\mathrm{X} 11(\mathrm{t})$ & $1.29(2.07)$ \\
\hline $\mathrm{X} 12(\mathrm{t})$ & $-0.09(-0.19)$ \\
\hline $\mathrm{X} 13(\mathrm{t})$ & $-1.93(-2.17)$ \\
\hline $\mathrm{X} 14(\mathrm{t})$ & $5.30(4.31)^{* *}$ \\
\hline $\mathrm{X} 15(\mathrm{t})$ & $-0.39(0.04)$ \\
\hline $\mathrm{X} 16(\mathrm{t})$ & $1.57(1.87)$ \\
\hline $\mathrm{R}^{2}$ & 0.97 \\
\hline $\mathrm{R}^{2}$ adjusted & 0.81 \\
\hline $\mathrm{F}$ & 6.068 \\
\hline No of observations & 20 \\
\hline & \\
\hline & \\
\hline & \\
\hline
\end{tabular}

** Significant at 0.05 level

Table 2. Estimation of Averages Key Variables of the Performance of Nigerian Banks Using Camel Ratios (2005-2009)

\begin{tabular}{|c|c|c|c|c|c|c|}
\hline Names of Banks & $\begin{array}{c}\text { AV Capital } \\
\text { adequacy }\end{array}$ & $\begin{array}{c}\text { AV Asset } \\
\text { quality }\end{array}$ & $\begin{array}{c}\text { AV Management } \\
\text { quality }\end{array}$ & $\begin{array}{c}\text { AV Earnings } \\
\text { ability }\end{array}$ & $\begin{array}{c}\text { AV } \\
\text { Liquidity }\end{array}$ & $\begin{array}{c}\text { CAMEL } \\
\text { Ratios }\end{array}$ \\
\hline Access Bank & 1.5 & 0.63 & 0.36 & 0.06 & 0.59 & 3.14 \\
\hline Afri Bank & 1.73 & 0.66 & 0.29 & 0.09 & 0.38 & 3.15 \\
\hline Diamond Bank & 1.39 & 0.09 & 0.42 & 0.06 & 031 & 2.27 \\
\hline Eco Bank & 1.96 & 0.22 & 0.35 & 0.07 & 0.31 & 2.91 \\
\hline Sterling Bank & 0.63 & 1.00 & 0.15 & 0.03 & 0.17 & 1.98 \\
\hline Fin Bank & 1.19 & 0.11 & 0.40 & 0.07 & 0.31 & 2.08 \\
\hline Fidelity Bank & 0.72 & 0.36 & 0.36 & 0.07 & 0.36 & 2.82 \\
\hline First Bank & 1.47 & 0.20 & 0.34 & 0.09 & 0.21 & 3.31 \\
\hline FCMB & 1.74 & 0.58 & 0.36 & 0.77 & 0.53 & 3.98 \\
\hline GTB & 1.48 & 0.67 & 0.37 & 0.07 & 0.72 & 3.31 \\
\hline Stanbic IBTC Bank & 1.55 & 0.20 & 0.35 & 0.09 & 0.28 & 2.47 \\
\hline IBPLC & 1.99 & 0.09 & 0.39 & 0.08 & 0.30 & 2.85 \\
\hline Oceanic Bank & 2.09 & 0.42 & 0.29 & 0.04 & 2.84 & 5.68 \\
\hline Bank PHB & 2.11 & 0.60 & 0.30 & 0.08 & 0.39 & 3.48 \\
\hline Skye Bank & 1.59 & 0.57 & 0.16 & 0.07 & 0.18 & 2.57 \\
\hline U.B.A. & 2.11 & 0.22 & 0.16 & 0.07 & 0.18 & 2.86 \\
\hline Union Bank & 2.25 & 0.79 & 0.21 & 0.11 & 0.38 & 3.74 \\
\hline Unity Bank & 2.16 & 0.25 & 0.23 & 0.02 & 0.19 & 2.85 \\
\hline Wema Bank & 2.13 & 0.22 & 0.43 & 0.01 & 0.36 & 3.15 \\
\hline Zenith Bank & 1.48 & 0.38 & 0.31 & 0.10 & 0.30 & 2.57 \\
\hline
\end{tabular}

Source: Field Survey, 2010 